iRAPA

\title{
Risk Perception of Tourist on the Competitiveness of Tourist Destination in Pattaya, Thailand
}

\author{
Maria Fe Imbonga* ${ }^{*}$ Yossamitt Kallayanapan ${ }^{b}$ \\ a Cebu Doctors University - Philippines \\ ${ }^{b}$ Maha Chulalongkorn Rajavidyalaya University - Thailand
}

\section{A R T I C L E I N F O}

\section{Article history:}

Received on: 13 December 2021

Revised on: 14 December 2021

Accepted on: 28 December 2021

Published on: 03 February 2022

\section{Keywords:}

Competitiveness

Pattaya

Thailand.

Tourism Development Plan

Tourist Destination

\begin{abstract}
A B S T R A C T
With globalization, tourism became a sustainable profitable industry. This study addresses tourist destination's competitiveness by determining its strength and assessing its weaknesses to attract tourist notwithstanding the threats and opportunities that they also are bestowed. This study is anchored on the Cluster Theory of Michael Porter (1990) that states that to be competitive, firms must continually improve operational effectiveness in their activities while simultaneously pursuing distinctive rather than imitative strategic positions. With the use of mixed research design, wherein, both descriptive quantitative correlational research design was used to determine the relationship between competitiveness and tourist destination appeal and risk of the tourist destination as perceived by the tourist, and the use of qualitative questions to draw significant attributes of Tourism competitiveness by interviewing destination managers as informants, the study revealed the characteristics and the average degree of competitiveness of Pattaya Tourists' Destinations that tourist perceived them vis-à-vis the low risk that the destination posed upon them. Furthermore, there is no significant relationship between the perceived factors affecting the competitiveness, and risks variables of Pattaya, Thailand as a tourist destination. There is no significant relationship between local and foreign tourist's perceptions. The study proposed an Enhanced Tourism Development Plan in Pattaya, Thailand.
\end{abstract}

Copyright (C) 2021 iRAPA International Journal of Business Studies. Published by International Research and Publishing Academy - Pakistan. This is an open access article licensed under CC BY:

(https://creativecommons.org/licenses/by/4.0)

\section{Introduction}

Tourism has become the most important activity in this new millennium. The contribution of Travel and Tourism industry to the world economy is significant. Although the growth in global tourism appears to continue at a rate comparable to other industries, tourism is in a mature stage leading to increasing competition among destinations (Buhalis 2000). Furthermore, Buhalis that $70 \%$ of all tourists visit the ten major world tourist destinations, leaving the rest of the world to share the remaining $30 \%$ of tourists. This suggests the power of competition for the other less known destinations. In 2016, four countries moved up in the Top 10 ranking by international tourism receipts and three in the ranking by international tourist arrivals (overnight visitors) making Thailand to rise in the ranking. (UNWTO Tourism Highlights 2017). Thailand is ranked number 35 in the World Travel \& Tourism Competitiveness Index 2015 Ranking. However, in Asia Pacific Region, Thailand ranked 10th while the Philippines ranked 14th Place and in the Southeast and Southern Asia, Thailand ranked 3rd while the Philippines ranked 7 th place. Accordingly, Thailand's environmental sustainability, ground and port

\footnotetext{
* Corresponding author: Yossamitt Kallayanapan, Maha Chulalongkorn

Rajavidyalaya University - Thailand

E-mail addresses: yossamitt@gmail.com
}

DOI: https://doi.org/10.48112/iijbs.v2i1.103

Copyright (C) 2021 RAPA International Journal of Business Studies

Published by International Research and Publishing Academy

This is an open access article licensed under CC BY

(https://creativecommons.org/licenses/by/4.0)

\section{How to cite:}

Imbong, M. F., \& Kallayanapan, Y. (2021). Risk Perception of Tourist on the Competitiveness of Tourist Destination in Pattaya, Thailand. iRAPA International Journal of Business Studies, 2(1), 12-21. https://doi.org/10.48112/iijbs.v2i1.103 
infrastructure and Cultural resources and business travel scored low. It scored high on Prioritization, International openness and price competitiveness, Air Transport infrastructure, Tourist Service Infrastructure, and Natural Resources. Pattaya, as Thailand's famous beach resort town has established a vibrant character over the years. Located near Bangkok International Airport, it's a convenient place to enjoy the sun, sand, and sea. This study focused on the competitiveness of Pattaya tourist destinations, as determined by its attractiveness to tourist and the risk perception of tourist on the different Pattaya Tourist destination.

Destination for tourist, is viewed in different perspective. Buhalis (2000) defines it as places that offer a mixture of tourism products and services, consumed under a brand name of the destination, arguing that these are well defined geographical regions, understood by visitors as unique entities with a core of six main provisions like attractions, accessibility, available packages of activities and ancillary services. Tourist destination from the demand perspective, is defined by Esteve (2003) and Leiper (1995), as cited by Faos-Sola, Eduardo, Alvarez, Maria and Cooper Chris (2014), as one that comprises all those local component being an objective of the tourist's visit, and for Cooper et al. (1998), Dwyer and Kim (2003, Hu and Ritchie (1993), Keller (2000), Pearce $(1981,1989)$ Tamma (2001) and Vera (1997) as cited by Faos-Sola, Eduardo, Alvarez, Maria and Cooper Chris (2014), the defined Tourism destination from the supply, spatial, and territorial perspective as destination that is a composite of goods and services performing in an interconnected way to satisfy the needs and expectations of tourist. From a systemic perspective, it is defined as a complex system, conformed by networks of agents and sub-systems of resources, services and products (Baggio,Scott and Cooper (2010), De Araujo and Bramwell,(2002) and Dredge (2006b) as cited by by FaosSola, Eduardo, Alvarez, Maria and Cooper Chris (2014),

Competitiveness is a multidimensional concept. It can be studied in three different levels: country, industry and firm. Competitive strategy according to Porter (1985) is aimed to establish a profitable and sustainable position against the forces that determine industry competition. In the context of tourism, the concept of competitiveness has been applied to different settings, linking it to economics, marketing and strategic perspectives, price, quality and satisfaction. According to Hassan (2000), a destination can be competitive if its market share which is measured by the number of visitors frequently visiting the place and financial returns are increasing. According to Ferrario (1979b) as cited by Vengesayi (2003), it is only when people are attracted to a destination that facilities and services follow. Thus, without this attractiveness, tourism will not exist and no tourist facilities and services will be offered for tourist to enjoy. The attractiveness will help people to decide in visiting again and spending time with that preferred destination.

In recent times, more people pay more attention to travel safely and avoid travel risks. Tourism risk perception is a quantitative assessment of tourism security that directly affects tourist purchase intention. Thus, tourist would like to be informed of the destination environment that he is supposed to go like physical risk, economic risk, equipment risk, social risk, psychological risk, time risk and opportunity loss (Cui, Fangnan \& Liu, Yaolong \& Chang, Yuanyuan \& Duan, Jin \& Li, Jizu.
(2016). Risk management in the tourism context refers to the planning and implementation of processes directed towards managing the adverse effects of crises and disasters on tourism. According to APEC International Centre for Sustainable Tourism Report 2006, risk management is concerned with identifying and analyzing the risks (the chance of something happening) to an organization or community and deciding what can or should be done to address these risks.

The study is anchored on the Cluster Theory of Michael Porter (1990) and Sebastian Vengesayi (2003). The cluster theory is a micro-economically based theory of national, state and local competitiveness which is put within the context of a global economy. According to Porter, to be competitive, firms must continually improve operational effectiveness in their activities while simultaneously pursuing distinctive rather than imitative strategic positions. His argument is that the existence of geographical clusters encourages both of the requirements for firm competitiveness, by encouraging the formation of regionally-based relational assets external to individual firms but of major benefit to their competitive performance.

Sebastian Vengesayi proposes that the popularity of tourism destinations can be enhanced by a combination of the factors of competitiveness and attractiveness. The competitiveness elements are derived from the supply side and the attractiveness from the demand side of tourism. The purpose of combining these perspectives is to come up with a holistic understanding of the destination popularity dynamics. The input of both tourists and tourist facility operators is necessary for any destination to manage and enhance its competitive advantage. He proposes that the evaluation of tourism destinations can be approached by symmetrically conceptualizing destination attractiveness and destination competitiveness as related and complementary dimensions. This approach allows comparisons to be made about the congruency between what the destinations invest in and what customers are looking for in a destination. Dwyer, Larry, Zelko Livaic and Robert Mellor (2003a) also undertook to contribute to the development of a general model of destination competitiveness. Their model also considers national and firm competitiveness theory as well as 'the main elements of destination competitiveness as proposed by tourism researchers ... and many of the variables and category headings identified by Crouch and Ritchie' (Dwyer, Larry, Zelko Livaic and Robert Mellor 2003a).

\section{Material \& Methods}

This study is a mixed quantitative and qualitative design. Its descriptive quantitative correlational research design component is used to determine the relationship between competitiveness and risk of the tourist destination with the local as well as foreign tourist as respondents. A key informant interview (KII) was used to address the qualitative component of this research. It used methodological triangulation (using two research method that of quantitative and qualitative) as well as data triangulation as data will be retrieved from a number of different sources (the opinion formers and opinion leaders) and data mining sources to form one body of data to increase credibility and validity of results. 
The study is focused on the tourist destinations in Pattaya, Thailand. Pattaya in Chonburi Province, is a town along Thailand's eastern Gulf coast known for a wild nightlife scene that attracts international visitors, weekenders from Bangkok and expats. A quiet fishing village as recently as the 1960 s, it is now lined with resort hotels, high-rise condos and a large seaside mall. Jet-skiing and parasailing are popular activities at Pattaya's busy beaches. Pattaya's weather is hot all year round. It has seasons namely the cool November to February, the hot March, April and May and the rainy June to October. The tourist destinations are all located in Pattaya, Thailand.

The respondent-participants of the study were composed of the tourist destination opinion formers and opinion leaders who answered the questionnaire on competitiveness; while the local and foreign tourist answered the destination's risk. Key informants of the study shared their insights and understanding of the qualitative question. Opinion formers are people or groups of people, representatives of advertising or travel agencies that can transmit the information to the consumer. They can present data and information about the tourist attractions, the natural and cultural environment, transport, prices, the estimated costs and so on, thus being able to influence the purchase decision of the potential clients. The tourism market can also be influenced by the information transmitted by personalities from various domains, like arts, sports and business who can express satisfaction with the chosen destination or the offered accommodation. Opinion leaders are people who are part of the same social category with the people they influence (neighbors, friends, co-workers, relatives and so on). They are experienced in the tourism field, have visited the offered destinations and can make knowledge based recommendations. Having a detailed knowledge of the destinations and tourist products allows creation of a promotion policy.

\section{Results \& Discussion}

Table 1

\begin{tabular}{ccc} 
Respondents/Participants of the Study & & \\
\hline Research Type & Frequency (N) & Percentage \\
\hline Quantitative Respondents & 50 & 45 \\
Tourist Destination opinion formers & & \\
\& Leaders & 50 & 45 \\
Tourist & 10 & 10 \\
Qualitative Respondents (KII) &
\end{tabular}

Opinion Leaders TOTAL 110 $100 \%$

The two instruments used in this study are the research made questionnaire, pre-tested for validity and reliability using cronbach alpha and the Interview guide. The first part of the questionnaire is the Level of Competitiveness of the Tourist Destination in terms of the attraction and mix of activities, facilities and tourism infrastructure, service environment and communication and promotion. The second part of the questionnaire is the level of risk and safety of the tourist destination as perceived by the tourist in terms of human and institutional development, risk in tourism of individual traveler, physical and environmental risk, and own safety and security and their host. The Key Informant Interview guide which was answered by the selected opinion leaders elicit the Key informant's insights and understanding of the questions asked such as his/er description of the following as it applies to Pattaya Tourism: a. Tourist performance and impacts; b. Ability of the destination to deliver quality and competitive tourism services; and c. Attractiveness of the tourist destination.

The quantitative analysis and interpretation used statistical treatment. The study used frequency and percentage for the table of participants, Weighted Mean to compute for the level of attractiveness and the level of risk of the tourist destination. The qualitative data was interpreted based on thematic approach and utilized the descriptive analysis. Qualitative data analysis is used in the data management of the interviews of the key informants. The triangulation sources are the transcript of the interviews from the different participants. The triangulations of participants are from the tourist destination opinion formers and leaders that formed the quantitative respondents, Opinion leaders and tourist who are the Qualitative respondents.

Pattaya as a tourist destination is characterized by increasing number of destinations opened every year since 2015 which registered 1 sites mostly sports offering services, in 2016 it registered 10 new sites mostly for viewing services, and the latest in 2017 are 4 new sites. The findings of the study revealed that the tourist destinations in terms of its competitiveness in attraction and mix of activities was rated as Fairly Competitive by local and foreign tourist and Opinion Leaders and was rated as Not Fairly Competitive or Falling Behind.

Table 2

Level of Competitiveness in terms of Attraction and Mix of Activities ( $\mathrm{n}=200)$

\begin{tabular}{|c|c|c|c|c|c|c|c|c|c|c|}
\hline & \multicolumn{4}{|c|}{ Tourist } & \multicolumn{4}{|c|}{ Opinion } & \multicolumn{2}{|c|}{ TOTALITY } \\
\hline & \multicolumn{2}{|c|}{ Foreign } & \multicolumn{2}{|c|}{ Local } & \multicolumn{2}{|c|}{ Formers } & \multicolumn{2}{|c|}{ Leaders } & & \\
\hline & WM & Descr & $\overline{\mathrm{WM}}$ & Descr & WM & Descr & WM & Descr & WM & Descr \\
\hline LEISURE TOURISM & 3.13 & FC & 3.04 & $\mathrm{FC}$ & 2.94 & $\mathrm{FC}$ & 2.93 & $\mathrm{FC}$ & 3.01 & $\mathrm{FC}$ \\
\hline HEALTH TOURISM & 2.11 & NFC & 2.21 & NFC & 1.92 & NFC & 1.95 & NFC & 2.05 & NFC \\
\hline $\begin{array}{c}\text { EDUC \& STUDY } \\
\text { TOURISM }\end{array}$ & 2.68 & $\mathrm{FC}$ & 2.60 & FC & 2.29 & NFC & 2.26 & NFC & 2.46 & NFC \\
\hline BUSINESS TOURISM & 2.38 & NFC & 2.31 & NFC & 2.26 & NFC & 2.27 & NFC & 2.31 & NFC \\
\hline RELIGIOUS & 2.02 & NFC & 2.16 & NFC & 2.36 & NFC & 2.36 & NFC & 2.23 & NFC \\
\hline SPORTS & 2.31 & NFC & 2.36 & NFC & 2.36 & NFC & 2.37 & NFC & 2.35 & NFC \\
\hline TOTAL & 2.51 & $\mathrm{FC}$ & 2.52 & $\mathrm{FC}$ & 2.50 & NFC & 2.52 & $\mathrm{FC}$ & 2.51 & $\mathrm{FC}$ \\
\hline
\end{tabular}

Leisure tourism consisted of adventure tourism, ecotourism, wine and nightlife and packaged beach tourism. Pattaya's landscape is reflected by coastal shoreline where nature, sand and fun is awaiting every 
tourist to enjoy. Below is the table that reflects the competitiveness of Pattaya in terms of its Leisure
Tourism.

Table 3

Level of Competitiveness in terms of Leisure Tourism $(n=200)$

\begin{tabular}{|c|c|c|c|c|c|c|c|c|c|c|}
\hline \multirow{3}{*}{ Indicators } & \multicolumn{4}{|c|}{ TOURIST } & \multicolumn{4}{|c|}{ Opinion } & \multirow{2}{*}{\multicolumn{2}{|c|}{ TOTALITY }} \\
\hline & \multicolumn{2}{|c|}{ Foreign } & \multicolumn{2}{|c|}{ Local } & \multicolumn{2}{|c|}{ Formers } & \multicolumn{2}{|c|}{ Leaders } & & \\
\hline & WM & Descr & WM & Descr & WM & Descr & WM & Descr & WM & Descr \\
\hline Adventure & 2.94 & $\mathrm{FC}$ & 2.88 & $\mathrm{FC}$ & 2.92 & $\mathrm{FC}$ & 3.00 & $\mathrm{FC}$ & 2.94 & FC \\
\hline Ecotourism & 2.78 & $\mathrm{FC}$ & 2.68 & $\mathrm{FC}$ & 2.34 & NFC & 2.22 & NFC & 2.51 & $\mathrm{FC}$ \\
\hline wine $\&$ Nightlife & 3.42 & $\mathrm{VC}$ & 3.30 & $\mathrm{VC}$ & 3.38 & $\mathrm{VC}$ & 3.38 & $\mathrm{VC}$ & 3.37 & $\mathrm{VC}$ \\
\hline Package Beach & 3.38 & $\mathrm{VC}$ & 3.30 & $\mathrm{VC}$ & 3.10 & $\mathrm{FC}$ & 3.12 & $\mathrm{FC}$ & 3.23 & $\mathrm{FC}$ \\
\hline TOTALITY & 3.13 & $\mathrm{FC}$ & 3.04 & $\mathrm{FC}$ & 2.94 & $\mathrm{FC}$ & 2.93 & $\mathrm{FC}$ & 3.01 & $\mathrm{FC}$ \\
\hline
\end{tabular}

Of the various indicators wine and nightlife is rated Very Competitive while all the other were rated Fairly Competitive. The Health Tourism in Pattaya consists of Wellness that includes spiritual, yoga, and meditation, new age, beauty treatment, sports \& fitness and pampering and Medical Health Tourism that includes medical wellness (therapeutic recreation, rehabilitation and lifestyle and occupational wellness), medical therapeutic (rehabilitation of illness related, healing and recuperation) and medical surgical (cosmetics, dentistry and operations). Below is the table showing the level of competitiveness of Health Tourism.

Table 4

Level of Competitiveness in terms of Health Tourism $(n=200)$

\begin{tabular}{|c|c|c|c|c|c|c|c|c|c|c|}
\hline & \multicolumn{4}{|c|}{ Tourist } & \multicolumn{4}{|c|}{ Opinion } & \multirow{2}{*}{\multicolumn{2}{|c|}{ TOTALITY }} \\
\hline & \multicolumn{2}{|c|}{ Foreign } & \multicolumn{2}{|c|}{ Local } & \multicolumn{2}{|c|}{ Formers } & \multicolumn{2}{|c|}{ Leaders } & & \\
\hline & WM & Descr & WM & Descr & WM & Descr & WM & Descr & WM & Descr \\
\hline Wellness & 2.13 & NFC & 2.23 & NFC & 2.06 & $\mathrm{NFC}$ & 2.08 & NFC & 2.13 & NFC \\
\hline Medical Health & 2.09 & NFC & 2.19 & NFC & 1.78 & NFC & 1.83 & NFC & 1.97 & NFC \\
\hline Totality & 2.11 & NFC & 2.21 & NFC & 1.92 & NFC & 1.95 & NFC & 2.05 & NFC \\
\hline
\end{tabular}

The table reflected that health tourism in Pattaya is Not Fairly Competitive both in wellness and in Medical Health. Also, all the four groups of respondents were assessing them as Not Fairly Competitive. Both foreign and local tourists were rating it more than the local opinion formers and leaders. There is a lot to improve in this sector. Table 5 below reflects the level of competitiveness of Pattaya in terms of Educational and Study Tourism determined b Educational Immersion and academic study.

Table 5

Level of Competitiveness in terms of Educational \& Study Tourism ( $\mathrm{n}=200)$

\begin{tabular}{|c|c|c|c|c|c|c|c|c|c|c|}
\hline & \multicolumn{4}{|c|}{ Tourist } & \multicolumn{4}{|c|}{ Opinion } & \multirow{2}{*}{\multicolumn{2}{|c|}{ TOTALITY }} \\
\hline & \multicolumn{2}{|c|}{ Foreign } & \multicolumn{2}{|c|}{ Local } & \multicolumn{2}{|c|}{ Formers } & \multicolumn{2}{|c|}{ Leaders } & & \\
\hline & WM & Descr & WM & Descr & WM & Descr & WM & Descr & WM & Descr \\
\hline Educational Immersion & 2.52 & $\mathrm{FC}$ & 2.50 & NFC & 2.62 & $\mathrm{FC}$ & 2.70 & $\mathrm{FC}$ & 2.59 & $\mathrm{FC}$ \\
\hline Academic Study & 2.84 & FC & 2.70 & FC & 1.96 & NFC & 1.82 & NFC & 2.33 & NFC \\
\hline Total & 2.68 & $\mathrm{FC}$ & 2.60 & $\mathrm{FC}$ & 2.29 & NFC & 2.26 & NFC & 2.46 & NFC \\
\hline
\end{tabular}

The table above tells that educational and study tourism is not yet fully developed area where local opinion forms and leaders were assessing it at as Not Fairly Competitive. They were convinced that something has to be done to improve this area of tourism in the Pattaya. However, the foreign and local tourists vis-à-vis the opinion formers and leaders were saying differently. Manat Chaisawat (2005) did a study on Baccalaureate and Graduate Degrees in tourism and hospitality studies in Thailand in 2003. Both studies also found that the quantity of graduates from the educational institutions was sufficiently to serve the demand of the industry. However, there were problems in terms of quality since graduates' qualifications were not up to the standards required by the employers. Table 6 below reflects the assessment of the level of competitiveness in terms of Business Tourism as determined by cultural immersion, business academic, meetings, incentives, conventions and exhibits.

Table 6

\begin{tabular}{|c|c|c|c|c|c|c|c|c|c|c|}
\hline & \multicolumn{4}{|c|}{ Tourist } & \multicolumn{4}{|c|}{ Opinion } & \multicolumn{2}{|c|}{ TOTALITY } \\
\hline & \multicolumn{2}{|c|}{ Foreign } & \multicolumn{2}{|c|}{ Local } & \multicolumn{2}{|c|}{ Formers } & \multicolumn{2}{|c|}{ Leaders } & & \\
\hline & WM & Descr & WM & Descr & WM & Descr & WM & Descr & WM & Descr \\
\hline 1.Cultural Immersion & 1.92 & NFC & 1.96 & NFC & 2.58 & FC & 2.66 & $\mathrm{FC}$ & 2.28 & NFC \\
\hline 2.Business Academic & 1.96 & NFC & 1.86 & NFC & 2.12 & $\mathrm{NFC}$ & 1.94 & $\mathrm{NFC}$ & 1.97 & NFC \\
\hline 3.Meetings & 2.54 & $\mathrm{FC}$ & 2.54 & $\mathrm{FC}$ & 2.66 & $\mathrm{FC}$ & 2.80 & $\mathrm{FC}$ & 2.64 & $\mathrm{FC}$ \\
\hline 4.Incentives & 2.72 & $\mathrm{FC}$ & 2.58 & $\mathrm{FC}$ & 2.20 & NFC & 2.26 & NFC & 2.44 & NFC \\
\hline 5.Conventions & 2.68 & $\mathrm{FC}$ & 2.50 & NFC & 2.12 & NFC & 2.04 & NFC & 2.34 & NFC \\
\hline 6.Exhibits & 2.44 & NFC & 2.40 & NFC & 1.90 & NFC & 1.94 & NFC & 2.17 & NFC \\
\hline Total & 2.38 & NFC & 2.31 & NFC & 2.26 & NFC & 2.27 & NFC & 2.31 & NFC \\
\hline
\end{tabular}


The table resulted to an over-all assessment of Not Fairly Competitive. This were assessed by all the respondents implying that there is a lot to improve in this area. The table below reflects the level of competitiveness in terms of religious tourism.

Table 7

Level of Competitiveness in terms of Religious Tourism ( $\mathrm{n}=200)$

\begin{tabular}{|c|c|c|c|c|c|c|c|c|c|c|}
\hline & \multicolumn{4}{|c|}{ TOURIST } & \multicolumn{4}{|c|}{ Opinion } & \multicolumn{2}{|c|}{ TOTALITY } \\
\hline & \multicolumn{2}{|c|}{ Foreign } & \multicolumn{2}{|c|}{ Local } & \multicolumn{2}{|c|}{ Formers } & \multicolumn{2}{|c|}{ Leaders } & & \\
\hline & WM & Descr & WM & Descr & WM & Descr & WM & Descr & WM & Descr \\
\hline 1.Visit to temples & 2.02 & NFC & 2.16 & NFC & 2.36 & NFC & 2.36 & NFC & 2.23 & NFC \\
\hline Total & 2.02 & NFC & 2.16 & NFC & 2.36 & NFC & 2.36 & NFC & 2.23 & NFC \\
\hline
\end{tabular}

Both the foreign tourist and local tourist assessed religious tourism at as Not Fairly Competitive, as well as the local opinion formers and leaders. The table below reflects the level of competitiveness in terms of sports tourism.

Table 8

Level of Competitiveness in terms of Sports Tourism $(n=200)$

\begin{tabular}{|c|c|c|c|c|c|c|c|c|c|c|}
\hline & \multicolumn{4}{|c|}{ Tourist } & \multicolumn{4}{|c|}{ Opinion } & \multirow{2}{*}{\multicolumn{2}{|c|}{ TOTALITY }} \\
\hline & \multicolumn{2}{|c|}{ Foreign } & \multicolumn{2}{|c|}{ Local } & \multicolumn{2}{|c|}{ Formers } & \multicolumn{2}{|c|}{ Leaders } & & \\
\hline & WM & Descr & WM & Descr & WM & Descr & WM & Descr & WM & Descr \\
\hline 1.Sports like Olympic & 2.16 & NFC & 2.18 & NFC & 2.06 & NFC & 1.96 & NFC & 2.09 & NFC \\
\hline 2.Surfing, Banana Boat, water ski & 2.32 & NFC & 2.38 & NFC & 3.02 & FC & 3.08 & $\mathrm{FC}$ & 2.70 & $\mathrm{FC}$ \\
\hline 3.Volleyball, beach soccer & 2.46 & NFC & 2.52 & $\mathrm{FC}$ & 2.00 & NFC & 2.06 & NFC & 2.26 & NFC \\
\hline Total & 2.31 & $\mathrm{NFC}$ & 2.36 & $\mathrm{NFC}$ & 2.36 & NFC & 2.37 & NFC & 2.35 & NFC \\
\hline
\end{tabular}

Table 8 above shows that Sport Tourism is something new for Thailand that is why it's not yet that popular among tourist and locals. Over all, they assessed it as Not Fairly Competitive. The level of competitiveness of the tourist destination in terms of Facilities and Tourism Infrastructure is assessed by the foreign tourist based on the facilities like accommodation facilities, food services, transportation facilities, highways, railways, bus services, airport and ferries and tourism infrastructure like availability and accessibility of cable cars, golf course, museums, theme parks, national parks, regional parks, amusement parks, traditional parks, water parks, marine parks, and rose parks. Table 9 reflects the assessment of the foreign tourist in terms of facilities and tourism infrastructure.

Table 9

Level of Competitiveness in terms of Facilities and Tourism Infrastructure $(n=200)$

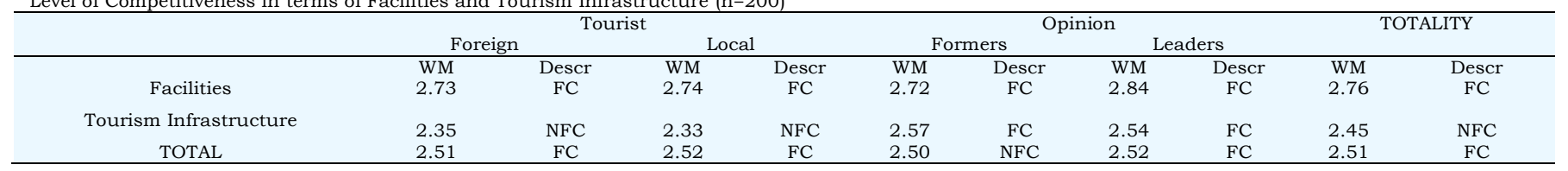

The table above reflects an assessment of the level of competitiveness in terms of facilities and Tourism Infrastructure as Fairly Competitive. Since there had been no articles on Pattaya's facilities and tourism infrastructure, the researcher believes that there are more improvements that can still be done in this area.
Facilities are composed accommodation facilities, food services, transportation services, highways, railways, bus services, airport services and ferries service. Table 10 presents the level of competitiveness of the facilities, determined by Accommodation facilities, Food Services, Transportation Services, Highways, Railways, Bus Services, Airport, and Ferries. 
Table 10

Level of Competitiveness in terms of Facilities ( $\mathrm{n}=200)$

\begin{tabular}{|c|c|c|c|c|c|c|c|c|c|c|}
\hline & \multicolumn{2}{|c|}{ Foreign Tourist } & \multicolumn{2}{|c|}{ Local Tourist } & \multicolumn{2}{|c|}{$\begin{array}{c}\text { Opinion } \\
\text { Formers } \\
\end{array}$} & \multicolumn{2}{|c|}{ Opinion Leaders } & \multicolumn{2}{|c|}{ Total } \\
\hline & WM & Desc & WM & Desc & WM & Desc & WM & Desc & WM & Desc \\
\hline Accommodation facilities & 3.18 & $\mathrm{FC}$ & 3.22 & $\mathrm{FC}$ & 3.30 & $\mathrm{VC}$ & 3.48 & $\mathrm{VC}$ & 3.30 & $\mathrm{VC}$ \\
\hline Food Services & 3.52 & $\mathrm{VC}$ & 3.60 & $\mathrm{VC}$ & 3.16 & FC & 3.16 & FC & 3.36 & VC \\
\hline Transportation Services & 2.64 & $\mathrm{FC}$ & 2.62 & $\mathrm{FC}$ & 2.56 & $\mathrm{FC}$ & 2.72 & $\mathrm{FC}$ & 2.64 & $\mathrm{FC}$ \\
\hline Highways & 3.26 & VC & 3.14 & $\mathrm{FC}$ & 2.56 & $\mathrm{FC}$ & 2.66 & $\mathrm{FC}$ & 2.91 & $\mathrm{FC}$ \\
\hline Railways & 2.32 & NFC & 2.24 & NFC & 2.30 & NFC & 2.40 & NFC & 2.32 & NFC \\
\hline Bus Services & 2.06 & NFC & 2.32 & NFC & 2.74 & $\mathrm{FC}$ & 2.92 & $\mathrm{FC}$ & 2.51 & $\mathrm{FC}$ \\
\hline Airport & 2.60 & $\mathrm{FC}$ & 2.54 & $\mathrm{FC}$ & 2.74 & $\mathrm{FC}$ & 2.94 & $\mathrm{FC}$ & 2.71 & $\mathrm{FC}$ \\
\hline Ferries & 2.26 & NFC & 2.22 & NFC & 2.38 & $\mathrm{NFC}$ & 2.4 & NFC & 2.32 & NFC \\
\hline Total & 2.73 & $\mathrm{FC}$ & 2.74 & $\mathrm{FC}$ & 2.72 & $\mathrm{FC}$ & 2.84 & $\mathrm{FC}$ & 2.76 & $\mathrm{FC}$ \\
\hline
\end{tabular}

The over-all level of competitiveness in terms of facilities is Fairly Competitive (FC). According to the Ministry of Foreign Affairs (2017) in the ASEAN Business Dialogue states that Thailand has a well-developed hotel industry. What is considered in this study as tourism infrastructure are the services of cable cars, golf courses, museums and other well-known parks. These infrastructures are not yet ready for Pattaya,Thailand. Thus the findings of Not Fairly Competitive. Table 11 presents the level of competitiveness of Tourism Infrastructure determined by existence of cable cars, golf course, museums, theme parks, national parks, regional parks, amusement parks, traditional parks, water parks, marine parks, and rose parks.

Table 11

Level of Competitiveness in terms of Tourism Infrastructure $(n=200$

\begin{tabular}{|c|c|c|c|c|c|c|c|c|c|c|}
\hline & \multicolumn{2}{|c|}{ Foreign Tourist } & \multicolumn{2}{|c|}{ Local Tourist } & \multicolumn{2}{|c|}{$\begin{array}{l}\text { Opinion } \\
\text { Formers } \\
\end{array}$} & \multicolumn{2}{|c|}{ Opinion Leaders } & \multicolumn{2}{|c|}{ Total } \\
\hline & WM & Desc & WM & Desc & WM & Desc & WM & Desc & WM & Desc \\
\hline Cable cars & 2.12 & NFC & 2.10 & NFC & 2.40 & NFC & 2.36 & NFC & 2.25 & NFC \\
\hline Golf Course & 2.94 & $\mathrm{FC}$ & 3.10 & $\mathrm{FC}$ & 3.40 & $\mathrm{VC}$ & 3.48 & $\mathrm{VC}$ & 2.23 & NFC \\
\hline Museums & 2.28 & NFC & 2.16 & $\mathrm{NFC}$ & 2.46 & $\mathrm{NFC}$ & 2.42 & NFC & 2.33 & NFC \\
\hline Theme Parks & 2.54 & $\mathrm{FC}$ & 2.64 & $\mathrm{FC}$ & 3.12 & $\mathrm{FC}$ & 3.24 & $\mathrm{FC}$ & 2.89 & $\mathrm{FC}$ \\
\hline National Parks & 2.62 & $\mathrm{FC}$ & 2.72 & $\mathrm{FC}$ & 2.68 & $\mathrm{FC}$ & 2.64 & $\mathrm{FC}$ & 2.67 & $\mathrm{FC}$ \\
\hline Regional Parks & 2.42 & NFC & 2.56 & $\mathrm{FC}$ & 2.34 & NFC & 2.26 & NFC & 2.40 & NFC \\
\hline Amusement Parks & 2.36 & NFC & 2.40 & NFC & 2.70 & $\mathrm{FC}$ & 2.46 & NFC & 2.48 & NFC \\
\hline Traditional Parks & 2.24 & NFC & 2.26 & NFC & 2.54 & $\mathrm{FC}$ & 2.54 & $\mathrm{FC}$ & 2.40 & NFC \\
\hline Water Parks & 3.16 & $\mathrm{FC}$ & 3.14 & $\mathrm{FC}$ & 3.22 & $\mathrm{FC}$ & 3.26 & $\mathrm{VC}$ & 3.20 & $\mathrm{FC}$ \\
\hline Marine Parks & 1.68 & $\mathrm{NC}$ & 1.08 & $\mathrm{NC}$ & 1.94 & $\mathrm{NFC}$ & 1.84 & $\mathrm{NFC}$ & 1.64 & $\mathrm{NC}$ \\
\hline Rose parks & 1.52 & $\mathrm{NC}$ & 1.52 & $\mathrm{NC}$ & 1.50 & $\mathrm{NC}$ & 1.46 & $\mathrm{NC}$ & 1.50 & $\mathrm{NC}$ \\
\hline Total & 2.35 & NFC & 2.33 & NFC & 2.57 & $\mathrm{FC}$ & 2.54 & $\mathrm{FC}$ & 2.45 & NFC \\
\hline
\end{tabular}

Because cable cars, golf courses, and museums are not available in Pattaya, that is why it scored (NFC) Not fairly Competitive or falling behind. They also do not have regional park, amusement parks and traditional parks that is why they scored it (NFC) Not fairly Competitive or falling behind. The level of competitiveness of the tourist destination in terms of Service Environment is assessed by the foreign tourist based on the scenery, natural hydrologic structures, clean water, fresh air and species diversity of Pattaya. Table 12 reflects the level of competitiveness in terms of Service Environment

Table 12

Level of Competitiveness in terms of Service Environment $(n=200)$

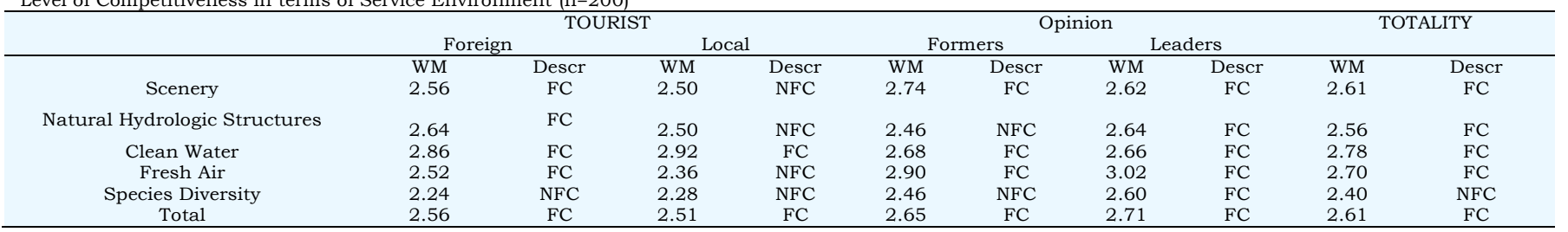

Over-all competitiveness in terms of service environment was rated Fairly Competitive. Table 13 presents the level of competitiveness in terms of Communication and Promotion determined by performance of Travel Agency, Tour Operators, T\&T Providers, Tourism Offices \& Information Centers, and Advertising: Print, TV, Billboard \& Social Media as perceived by tourist and opinion formers and leaders. 
Table 13

Level of Competitiveness in terms of Communication and Promotion $(\mathrm{N}=200)$

\begin{tabular}{|c|c|c|c|c|c|c|c|c|c|c|}
\hline & \multicolumn{4}{|c|}{ TOURIST } & \multicolumn{4}{|c|}{ Opinion } & \multirow{2}{*}{\multicolumn{2}{|c|}{ TOTALITY }} \\
\hline & \multicolumn{2}{|c|}{ Foreign } & \multicolumn{2}{|c|}{ Local } & \multicolumn{2}{|c|}{ Formers } & \multicolumn{2}{|c|}{ Leaders } & & \\
\hline & WM & Descr & WM & Descr & WM & Descr & WM & Descr & WM & Descr \\
\hline $\begin{array}{l}\text { Travel Agency, Tour Operators, } \\
\text { T\&T Providers }\end{array}$ & 3.20 & FC & 3.24 & FC & 3.24 & $\mathrm{FC}$ & 3.30 & VC & 3.25 & $\mathrm{FC}$ \\
\hline $\begin{array}{c}\text { Tourism Offices \& Information } \\
\text { Centers }\end{array}$ & 2.98 & $\mathrm{FC}$ & 3.08 & FC & 2.88 & $\mathrm{FC}$ & 2.86 & $\mathrm{FCC}$ & 2.95 & $\mathrm{FC}$ \\
\hline $\begin{array}{c}\text { Advertising: Print, TV, Billboard \& } \\
\text { Social Media }\end{array}$ & 2.42 & NFC & 2.56 & $\mathrm{FC}$ & 2.58 & $\mathrm{FC}$ & 2.82 & $\mathrm{FC}$ & 2.60 & $\mathrm{FC}$ \\
\hline Total & 2.87 & $\mathrm{FC}$ & 2.96 & $\mathrm{FC}$ & 2.90 & $\mathrm{FC}$ & 2.99 & $\mathrm{FC}$ & 2.93 & $\mathrm{FC}$ \\
\hline
\end{tabular}

Below is the summary table of the level of competitiveness according to the key informants.

Table 14

Summary of the Level of Competitiveness $(\mathrm{N}=200)$

\begin{tabular}{|c|c|c|c|c|c|c|c|c|c|c|}
\hline & \multicolumn{4}{|c|}{ Tourist } & \multicolumn{4}{|c|}{ Opinion } & \multirow{2}{*}{\multicolumn{2}{|c|}{ TOTALITY }} \\
\hline & \multicolumn{2}{|c|}{ Foreign } & \multicolumn{2}{|c|}{ Local } & \multicolumn{2}{|c|}{ Formers } & \multicolumn{2}{|c|}{ Leaders } & & \\
\hline & WM & Descr & WM & Descr & WM & Descr & WM & Descr & WM & Descr \\
\hline Attractions \& Mix of Activities & 2.44 & NFC & 2.45 & NFC & 2.35 & NFC & 2.36 & NFC & 2.40 & $\mathrm{NFC}$ \\
\hline Facilities \& Infrastructures & 2.54 & $\mathrm{FC}$ & 2.54 & $\mathrm{FC}$ & 2.65 & $\mathrm{FC}$ & 2.69 & FC & 2.60 & FC \\
\hline Service Environment & 2.56 & FC & 2.51 & $\mathrm{FC}$ & 2.65 & $\mathrm{FC}$ & 2.71 & $\mathrm{FC}$ & 2.61 & FC \\
\hline Communication and Promotion & 2.87 & $\mathrm{FC}$ & 2.96 & $\mathrm{FC}$ & 2.90 & $\mathrm{FC}$ & 2.99 & $\mathrm{FC}$ & 2.93 & $\mathrm{FC}$ \\
\hline Total & 2.51 & $\mathrm{FC}$ & 2.52 & $\mathrm{FC}$ & 2.50 & NFC & 2.52 & $\mathrm{FC}$ & 2.51 & FC \\
\hline
\end{tabular}

The over-all level of competiveness was rated (FC) Fairly Competitive or Average. All its variables were also rated (FC) Fairly Competitive except attraction and mixture. The level of risks is determined by Human \& Institutional Environment, Risk in Tourism \& Related Sectors,
Physical and Environmental Risk, and Own Safety and Security and their Host. Table 15 reflects risks in terms of human \& Institutional environment determined by theft, assault, burglary, fraud, deception and pick picket.

Table 15

Level of Risk in terms of Human \& Institutional Environment (n=100)

\begin{tabular}{|c|c|c|c|c|c|c|}
\hline & \multicolumn{4}{|c|}{ TOURIST } & \multicolumn{2}{|c|}{ TOTALITY } \\
\hline & \multicolumn{2}{|c|}{ Local } & \multicolumn{2}{|c|}{ Foreign } & & \\
\hline & WM & Descr & WM & Descr & WM & Descr \\
\hline Theft, assault, burglary, fraud, deception, pickpocket & 2.48 & LR & 2.32 & LR & 2.40 & LR \\
\hline Harassment & 2.12 & LR & 2.00 & LR & 2.06 & LR \\
\hline Extortion, slave trade, coercion & 1.94 & LR & 1.98 & LR & 1.96 & LR \\
\hline Hostage taking $\&$ other unlawful interference & 1.60 & NR & 1.58 & NR & 1.59 & NR \\
\hline Wars, social conflicts, political \& religious unrest & 1.68 & NR & 1.50 & NR & 1.59 & NR \\
\hline Total & 1.96 & LR & 1.88 & LR & 1.92 & LR \\
\hline
\end{tabular}

Liu, et. al. (2007) highlighted the importance of tourists' personal security and safety, especially against terrorism. The level of Risks of the tourist destinations in terms of Risk in Tourism \& Related Sectors is determined by Poor Safety Standards in Fire Safety, Poor Sanitation \& Disrespect for Environmental Sustainability, Absence of protection against unlawful Interference, crime \& delinquency at Tourism facilities, Fraud in commercial transactions, Non-compliance with contracts, and Industrial disputes with staff. Table 16 reflects risks in terms of of Risk in Tourism \& Related Sectors: 
Table 16

Level of Risk in terms of Risk in Tourism \& Related Sectors ( $N=100)$

\begin{tabular}{|c|c|c|c|c|c|c|}
\hline & \multicolumn{4}{|c|}{ TOURIST } & \multicolumn{2}{|c|}{ TOTALITY } \\
\hline & \multicolumn{2}{|c|}{ Local } & \multicolumn{2}{|c|}{ Foreign } & & \\
\hline & WM & Descr & WM & Descr & WM & Descr \\
\hline A. Poor Safety Standards in Fire Safety & 1.92 & LR & 2.22 & LR & 2.07 & LR \\
\hline B. Poor Safety Standards in & 2.20 & LR & 1.62 & NR & 1.91 & LR \\
\hline $\begin{array}{c}\text { C. Poor Safety Standards or Missing } \\
\text { Anti-Semitic Protection }\end{array}$ & 1.70 & NR & 2.02 & LR & 1.86 & LR \\
\hline Poor Sanitation \& Disrespect for Environmental Sustainability & 2.02 & LR & 1.88 & LR & 1.95 & LR \\
\hline $\begin{array}{c}\text { Absence of protection against unlawful } \\
\text { Interference, crime \& delinquency at } \\
\text { Tourism facilities }\end{array}$ & 2.26 & LR & 2.32 & LR & 2.29 & LR \\
\hline Fraud in commercial transactions & 1.82 & LR & 1.82 & LR & 1.82 & LR \\
\hline Non-compliance with contracts & 2.28 & LR & 2.10 & LR & 2.19 & LR \\
\hline Industrial disputes with staff & 1.76 & LR & 1.92 & LR & 1.84 & LR \\
\hline Total & 2.00 & LR & 1.99 & LR & 1.99 & LR \\
\hline
\end{tabular}

The over-all Tourism and Related Sector Risk was perceived by both local and foreign tourists as of Little Risk. The level of Risks of the tourist destinations in terms of Risk in Physical and Environmental Risk is determined by unaware of the natural characteristics of the destination, adequate medical preparations for the trips (vaccinations, prophylaxis), not taking the necessary precautions when consuming food or drink or in their personal hygiene, and exposure to dangerous situations arising from the physical environment. Table 17 reflects risks in terms of Risk in Physical and Environmental Risk:

Table 17

Level of Risk in terms of Physical and Environmental Risk (N=100)

\begin{tabular}{|c|c|c|c|c|c|c|}
\hline \multirow[b]{3}{*}{ Travellers: } & \multicolumn{4}{|c|}{ TOURIST } & \multirow{2}{*}{\multicolumn{2}{|c|}{ TOTALITY }} \\
\hline & \multicolumn{2}{|c|}{ Local } & \multicolumn{2}{|c|}{ Foreign } & & \\
\hline & WM & Descr & WM & Descr & WM & Descr \\
\hline $\begin{array}{l}\text { Are unaware of the natural characteristics of the destination (flora } \\
\text { and fauna) }\end{array}$ & 2.36 & LR & 2.16 & LR & 2.26 & LR \\
\hline $\begin{array}{l}\text { Have not undertaken adequate medical preparations for the trips ( } \\
\text { vaccinations, prophylaxis) }\end{array}$ & 2.38 & LR & 2.22 & LR & 2.30 & LR \\
\hline $\begin{array}{c}\text { Do not take the necessary precautions when consuming food or } \\
\text { drink or in their personal hygiene }\end{array}$ & 2.14 & LR & 2.30 & LR & 2.22 & LR \\
\hline $\begin{array}{c}\text { Are-exposed to dangerous situations arising from the physical } \\
\text { environment. }\end{array}$ & 2.18 & LR & 2.08 & LR & 2.13 & LR \\
\hline Total & 2.27 & LR & 2.19 & LR & 2.23 & LR \\
\hline
\end{tabular}

The over-all Physical and Environmental Risk was perceived by both local and foreign tourists as Little Risk. The level of Risks of the tourist destinations in terms of Own Safety and Security and their Host is determined by The practice of dangerous sports and leisure activities like dangerous driving and consuming unsafe food \& drink, travelling when in poor health which deteriorates during the trip, causing conflict and friction with local residents through inadequate behavior or by breaking the law, carrying out illicit or criminal activity like drug trafficking, and Visiting dangerous areas. Table 18 reflects risks in terms of Own Safety and Security and their Host:

Table 18

Level of Risk in terms of Own Safety and Security and their Host (N=100)

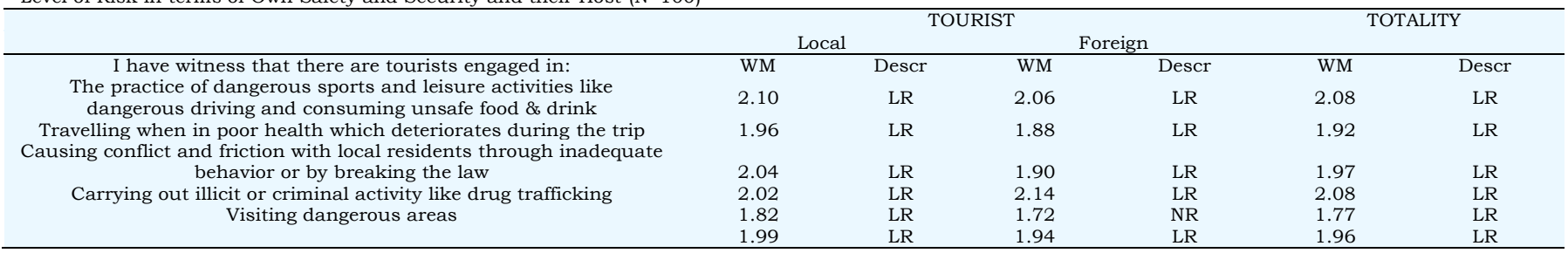

The over-all Own Safety and That of as of Little Risk Risk. Below is the summary of the level of risks as perceived by both local and foreign tourist. was perceived by both local and foreign tourists as Little 
Table 19

Summary of Level of Risk (N=100)

\begin{tabular}{|c|c|c|c|c|c|c|}
\hline & \multicolumn{4}{|c|}{ TOURIST } & \multicolumn{2}{|c|}{ TOTALITY } \\
\hline & \multicolumn{2}{|c|}{ Local } & \multicolumn{2}{|c|}{ Foreign } & & \\
\hline & WM & Descr & WM & Descr & WM & Descr \\
\hline Human $\&$ Institutional Environment & 1.96 & LR & 1.88 & LR & 1.92 & LR \\
\hline Tourism \& Related Sectors & 2.00 & LR & 1.99 & LR & 1.99 & LR \\
\hline Physical and Environmental Risk & 2.27 & LR & 2.19 & LR & 2.23 & LR \\
\hline Own Safety and Security and their Host & 1.99 & LR & 1.94 & LR & 1.96 & LR \\
\hline Total & 2.05 & LR & 2.00 & LR & 2.03 & LR \\
\hline
\end{tabular}

The qualitative component of the study reveals the following: The 10 Key informants are the opinion leaders who are experienced in the tourism field, have visited the offered destinations and they can make knowledge based recommendations. The interview resulted in a transcript that was analyzed based on thematic analysis, the following themes emerged: On the challenges that discouraged competitiveness and tourist destination appeal, the following are the emergent themes:

\section{Theme \# 1: Bar Girls}

Theme \#2: Traffic and lack of infrastructure vis-avis population growth

Theme\#3: Crowding

Theme\#4: Entrance Fee for tourist is expensive

On tourist performance and impacts of Pattaya Tourism Industry, the following are the emergent themes:

Theme \#1: Variety of water activities

Theme\#2: Excellence in tourist visit

Theme \#3: Hidden charges collected through force maneuver

\section{Conclusions}

The over-all tourism competiveness for Pattaya, Thaliand's tourist destination was rated (FC) Fairly Competitive or Average. All its variables were also rated (FC) Fairly Competitive except attraction and mixture. Thus, respondents survey suggested that Pattaya is a great tourist destination, although not the Leading tourist destination in Thailand, according to this study's survey. The over-all risks perceptions for both respondent-groups was at the Low Risk level including all factors such as Human and Institutional Environment; Tourism and Related Sectors; Physical and environment; and Own and tourist Host Safety and Security. These results suggested that, Pattaya is a Low Risk destination, thereby making it an ideal destination for local and foreign tourists of any kind of religion, since tourist's personal safety and security is of utmost importance (Liu, A. and Pratt, S., 2017). Furthermore, there is no significant relationship between the perceived factors affecting the competitiveness, and risks variables of Pattaya, Thailand as a tourist destination. There is no significant relationship between local and foreign tourist's perceptions.

Based on the findings and conclusion made, it was highly recommended that: a. There should be an extensive research to be made on this aspect to be sponsored by both the Tourism Authority in Thailand and local Pattaya communities, epically to be led by tourism agents and prime businesses benefactors

b. Pattaya has to intensity its tourism marketing and promotion of tourists' destinations, least it will be taken over $\mathrm{bb}$ other regional tourism powerhouses, e.g., the Phillipines

c. Development and training of the tourism human capital, in cooperation with both the academe, government tourism authority and the private tourism businesses

d. Infrastructure and products interconnectivity of the diversified Pattaya tourist destination

e. Consolidation of both government, private businesses and local communities' tourism investments

f. Despite being perceived a Low Risk tourism spot, there is still and always be a need for strengthened and continually improved Tourists' security and safety policies

g. Enhance local and private (especially tourism businesses) policies that promote the protection and preservation of nature, the environment and the natural and cultural heritage of Pattaya, Thailand

\section{References}

APEC International Centre for Sustainable Tourism Report 2006

Buhalis, D. (2000) Marketing the Competitive Destination of the Future. Tourism Management, 21, 97-116. http://dx.doi.org/10.1016/S0261-5177(99)00095-3

Cui, Fangnan \& Liu, Yaolong \& Chang, Yuanyuan \& Duan, Jin \& Li, Jizu. (2016). An overview of tourism risk perception. Natural Hazards. 82. 10.1007/s11069-016-2208-1.

Dwyer, Larry, Zelko Livaic and Robert Mellor (2003a), "Competitiveness Australia as a Tourist Destination," Journal of Hospitality and Tourist Management, 10(1), 60-78.

Faos-Sola, Eduardo, Alvarez, Maria and Cooper Chris (2014). Tourism as an Instrument for Development: A Theoretical and Practical Study. Volume 5. Emerald Gold Publishing Limited.

Hassan, S. (2000). Determinants of Market Competitiveness in an Environmentally Sustainable Tourism Industry. Journal of Travel Research,38 (February), 239-245.

Liu, A. and Pratt, S., (2017). Tourism's vulnerability and resilience to terrorism, Tourism Management, Volume 60, 2017, Pages 404-417, ISSN 0261-5177, https://doi.org/10.1016/j.tourman.2017.01.001.(http s://www.sciencedirect.com/science/article/pii/S0261 $517717300018)$

Manat Chaisawat (2005) Travel and Tourism Education in Thailand, Journal of Teaching in Travel \& Tourism, 5:3, 197-224, DOI: 10.1300/J172v05n03_02 
Ministry of Foreign Affairs (2017) in the ASEAN Business Dialogue

Porter Michael (1990). Clusters and the New Economics of Competition. Harvard Business Publishing. Copright@2021 Harvard Business School Publishing

UNWTO Tourism Highlights 2017

Vengesayi, Sebastian. (2003). A conceptual model of tourism destination competitiveness and attractiveness.

World Tourism Organization, (2003b)

World Travel \& Tourism Competitiveness Index 2015 Ranking 